\title{
Brasil delivery: A política econômica do governo Lula
}

\author{
Brazil "delivery": The political economy \\ of the Lula government
}

LEDA MARIA PAULANI*

"José Dirceu pronunciou um discurso que nem o Pedro Malan faria..."

(Olavo Setúbal, presidente do Conselho de Administração do Itaú, em entrevista à Carta Capital de 25/6/2003)

RESUMO: Este artigo discute a nova política econômica do governo brasileiro no início de 2003. Argumenta que, surpreendentemente, o governo do PT (Partido dos Trabalhadores) caiu na perversa lógica da "credibilidade". Essa lógica implica a morte da macroeconomia e impedirá a retomada imperativa do crescimento. Além disso, demonstra que os argumentos do governo para justificar essa rendição incondicional à economia ortodoxa não fazem sentido, porque não é possível provar que a economia brasileira estava caindo no início do novo governo. Sugere também que a identificação espúria entre administração responsável e política econômica liberal pode ser apontada como uma das razões desse surpreendente resultado.

PALAVRAS-CHAVE: Governo Lula; economia brasileira; política econômica; financeirização; neoliberalismo.

ABSTRACT: This paper discusses the new Brazilian government's economic policy at the beginning of 2003. It argues that surprisingly the government of PT (Worker's Party) has fallen into the perverse logic of "credibility". This logic implies the death of macroeconomics and will impede the imperative retaking of growth. Furthermore, it demonstrates that the arguments of government to justify this unconditional surrender to orthodox economics makes no sense because it is not possible to prove that Brazilian economy was falling down a precipice at the beginning of the new administration. It also suggests that the spurious identifica-

*Professora do Departamento de Economia da FEA/USP. E-mail: paulani@uol.com.br. 
tion between responsible administration and liberal economic policy may be pointed as one of the reasons of this astonishing result.

KEYWORDS: Lula government; Brazilian economy; economic policy; financialization; neoliberalism.

JEL Classification: F65; G28; O54.

\section{A MORTE DA MACROECONOMIA}

Desde que assumiu, em janeiro de 2003, o governo Lula vem praticando uma política econômica de inclinação inequivocamente liberal, confirmando o que muitos esperavam, alguns com angústia, outros com alívio. Teses e argumentos incansavelmente defendidos ao longo dos oitos anos de governo FHC, sempre criticados pelo Partido dos Trabalhadores, são agora afirmados pelo governo do PT com desconcertante naturalidade.

Acreditam alguns que a gestão Lula será ainda mais liberal que a de seu antecessor, conseguindo levar a cabo uma série de transformações com as quais FHC apenas sonhou. Angeli, em charge na Folha de S. Paulo de 26 de abril, traduz à perfeição essa expectativa: diante do retrato do presidente Lula, o primeiro indivíduo toma-o por um sósia de FHC, o segundo, em dúvida, argumenta que "este é mais gordinho", ao que o terceiro retruca: "que nada, esse é o FHC verdadeiro".

Ainda que não seja uma completa surpresa - para alguns essa manobra radical já estava em germe no início de 2002 e para outros antes mesmo disso - o cenário impõe reflexão: quais as razões de tamanha virada? quais os limites dessa política?

Comecemos pelas razões. A primeira alegada razão é sobejamente conhecida. Mesmo o mais distraído observador da cena nacional a tem na ponta da língua. Trata-se da famosa TINA (There Is No Alternative), na qual estivemos submersos nos últimos oito anos e da qual muitos acreditaram que iríamos sair, ou, ao menos, erguer um pouco a cabeça.

O primeiro elo da cadeia argumentativa que sustenta a força da TINA é que existe só uma macroeconomia. Repetido hoje de A a Z, ou seja, por economistas das mais variadas filiações ideológicas, o argumento reza que não há política econômica de direita, de esquerda ou de centro. Existe a política certa, tecnicamente (sic) fundamentada, neutra; e a política errada, irresponsável, utópica, ingênua, populista. Portanto, todo e qualquer ajuste só pode se dar na esfera microeconômica: o spread bancário é alto? mexa-se na lei de falências; a renda é mal distribuída? basta "focar" os programas sociais e aumentar sua eficiência; e assim por diante. São intocáveis o ajuste fiscal "duro", o juro real elevado, a política monetária contracionista, o câmbio flutuante, a livre movimentação dos capitais. 
Portanto, se só há uma política macroeconômica cientificamente comprovada, um governo responsável, qualquer que seja sua filiação ideológica, deverá adotála. O matiz ideológico fica assim relegado à condução de políticas de enfoque microeconômico: mais ativamente "pró-social" para os de esquerda (políticas compensatórias etc.), menos preocupadas com o "social" para os de direita. ${ }^{1}$

Não é demais lembrar que essa política macroeconômica, considerada a única correta porque a única verdadeiramente científica, implica, particularmente no caso de economias como a brasileira, a extinção do espaço em si da política econômica: a política monetária fica atrelada às metas inflacionárias, a fiscal aos superávits e a cambial é comandada pelo próprio mercado. Nesse contexto, aliás, não há rigorosamente nenhuma diferença entre a independência do Banco Central e sua "autonomia operacional".

\section{A LÓGICA DA CREDIBILIDADE}

Assim, numa economia como a nossa, ceder aos apelos do crescimento e do aumento do emprego mexendo em qualquer dos dogmas da política econômica cientificamente comprovada, implica pôr em risco a "credibilidade", segundo elo da cadeia argumentativa que sustenta a TINA.

A necessidade de recuperar a "credibilidade" do país foi e é utilizada como justificativa número um para a manutenção e mesmo a exacerbação, neste início de governo, da política econômica operada pelo governo FHC. Mas, colocada dessa forma, ela gera a expectativa de um espaço para a alteração dessa política, uma vez recuperada a dita credibilidade. A queda acelerada do risco-país, a recuperação do preço dos C-Bonds e a tão festejada valorização do real começaram a apontar para isso pelo menos desde o início de abril de 2003. Os jornais passaram então a dizer que "o Brasil virou moda em Wall Street", e que, para os investidores estrangeiros, "Lula é um bom negócio".

Teria chegado com isso, finalmente, a hora e a vez da política econômica indutora do crescimento e do emprego? Ledo engano. Além de não tomar nenhuma medida sinalizadora de uma tal política nas demais áreas, como, por exemplo, a fiscal, no que tange à sua face mais visível, a área monetária, também nada mudou. O Copom, desde então, manteve praticamente inalterada a taxa básica da economia

\footnotetext{
${ }^{1}$ Não é preciso dizer o quanto há de ideológico nessa forma de colocar as coisas. Reconhecer a existência do problema do "social" - forma de falar que vem se consagrando nos últimos anos - implica tomar espuriamente o todo como se fosse só uma parte, e certamente não a mais importante, da questão nacional. Evidentemente essa forma de expressão, e outras que lhe são correlatas, não estão desvinculadas da idéia de que só há uma macroeconomia. Pelo contrário, elas reafirmam a tese de que a economia, macroeconomicamente falando, deve ser tratada pelos governos "em separado" do "restante" dos problemas. O conteúdo desse discurso, mas que não pode ser plenamente descortinado, sob pena de comprometimento de seus propósitos, é que economia e sociedade devem ser consideradas como dois mundos que não se conectam.
} 
em torno dos $26 \%$ ao ano, ${ }^{2}$ uma elevação de 8 pontos percentuais relativamente à taxa vigente em julho e de 4 pontos percentuais relativamente à vigente em dezembro de 2002.

O equívoco, porém, não é de quem manteve a política monetária, que, para não dar margem a dúvidas, impusera, em fevereiro, via aumento do compulsório dos bancos, um corte de liquidez que atingiu quase $10 \%$ dos meios de pagamento da economia. O engano é de quem acreditou ou acredita que a rendição do governo petista ao canto de sereia do discurso liberal é apenas temporária e estratégica, necessária para "fazer a travessia" e garantir uma "transição sem traumas".

As autoridades econômicas deixaram muito claro, desde o início da gestão Lula, que seria esse o modelo a ser seguido e que, portanto, a recuperação da economia do país, a retomada do crescimento e a redução do desemprego teriam que se encaixar dentro dessas regras ou então não se efetivariam. Em texto recente, ${ }^{3} \mathrm{o}$ Prof. João Machado Borges Neto mostra, com profusão de detalhes, o passo-a-passo da conversão petista aos ditames da política liberal. Numa acurada análise do discurso de posse proferido pelo ministro Antonio Palocci em 2 de janeiro de 2003, ele indica que há uma confusão no que se vem entendendo por "transição". O mandatário número um do ministério mais importante da área econômica deixa aí claro que a tão esperada transição refere-se à superação das dificuldades de curto prazo dentro do mesmo modelo, que, segundo o ministro, é aquele que respeita os "princípios básicos da política econômica". Não se vislumbra, portanto, no horizonte da atual gestão, nenhuma mudança de modelo. ${ }^{4}$

Posição coerente, sem dúvida, visto que qualquer sinalização, por tênue que fosse, na direção de uma efetiva mudança, invertendo prioridades e dando primazia à recuperação do crescimento e do emprego, poria por terra essa tal "credibilidade". De fato, a lógica segundo a qual ela opera não permite tal violação. Uma vez conquistada, a "credibilidade" cobra um preço alto pela fidelidade: a manutenção de todos os mimos que permitiram sua conquista, a saber, a política monetária contracionista, o juro real elevado, o ajuste fiscal duro etc. Portanto, se equivoca quem esperava ou ainda espera por uma mudança efetiva. Crescimento econômico e redução do desemprego serão aqueles permitidos pelo modelo. Nesses marcos, eles nunca poderão ter primazia, ou seja, nunca passarão a ser o objetivo número um da política econômica, simplesmente porque isso é incompatível com os "princípios

\footnotetext{
${ }^{2}$ A reunião de abril retirou o viés de alta da taxa básica, mantendo-a porém nos $26,5 \%$ que vigoravam desde fevereiro. A reunião de maio não mudou nada nessa situação e a reunião de junho cortou irrisórios $0,5 \%$.

3 “Um governo contraditório", Revista da Sociedade Brasileira de Economia Política, n 12, junho de 2003.

${ }^{4}$ Em 17 de março de 2003, o secretário de política econômica do Ministério da Fazenda, Marcos Lisboa, afirmou em entrevista à Folha de S. Paulo que espera que o Brasil cresça em 2003 mais do que "vem crescendo recentemente". "Mas, no caso de o Brasil não voltar a crescer, o governo tem um plano B?", pergunta o repórter. "Não tem plano B. Isso faz parte de especulações naturais que sempre ocorrem", foi a resposta de Lisboa.
} 
básicos" do modelo adotado. Em poucas palavras, se for possível obter também esses resultados, por pífios que sejam, ótimo. Se não... paciência. Mas sendo assim, de que serve então a tão buscada e defendida credibilidade?

\section{BRASIL DELIVERY, OU PARA QUE SERVE A CREDIBILIDADE}

Se não é para permitir prioritariamente a retomada do crescimento econômico e do emprego, de que serve então a conquista dessa tal credibilidade? Perguntemos, em primeiro lugar, pelas suas conseqüências. A mais badalada delas foi a súbita engorda da balança de capitais nos primeiros meses de 2003, o que explica, como se sabe, a acelerada queda de valor da moeda americana que se seguiu. Mas que dólar é esse? "País atrai capital volátil; dólar produtivo seca", diz a manchete do caderno "Dinheiro" da Folha de S. Paulo de 25 de abril. Ao contrário do ocorrido com o capital de curto prazo, cujas entradas cresceram mais de $1.300 \%$ no primeiro trimestre deste ano comparado ao mesmo período de 2002, a entrada de capital resultante de investimentos diretos estrangeiros, no mesmo período e comparada a base idêntica, caiu quase $58 \%$. Tal assimetria explica-se, de um lado, pela inevitável arbitragem operada pelos mercados em condições de risco reduzido e taxa real de juros elevada e, de outro, pelo esgotamento da fonte que produziu, em anos anteriores, os polpudos recursos oriundos de investimentos estrangeiros diretos ${ }^{5}$ (não há quase mais nada que privatizar e o capital privado de bom potencial e preços irrisórios já foi praticamente todo negociado). ${ }^{6}$

Ressalve-se, porém, que, mesmo que os recursos em tela tivessem se originado da banda saudável da balança de capitais, as conseqüências do ponto de vista da performance futura das contas externas seriam praticamente as mesmas, a saber, valorização da moeda doméstica e piora nos resultados da balança comercial e da balança de serviços não fatores. Daí à decisão de financiar com recursos provenientes da movimentação de estoques o pesado déficit em transações correntes, portanto, déficit de fluxo, do balanço de pagamentos, é só um pulinho. Não há espírito

\footnotetext{
${ }^{5}$ No início deste ano a previsão do governo era que entrariam pelo menos US\$ 16 bilhões na balança de capitais em 2003 na rubrica investimentos externos diretos (IDE). Essa previsão foi revista em março para US\$ 13 bilhões, e em seguida para US\$ 11 bilhões. O mercado, porém, não acredita em nada maior do que US\$ 8 bilhões.

${ }^{6}$ A reforma da Previdência, na forma como está sendo proposta, com a insistência no regime único ou assemelhado e na fixação de um teto bastante reduzido para os benefícios a serem pagos pelo Estado, deverá redundar num processo de abertura à exploração por parte do setor privado nacional e internacional de um mercado previdenciário substantivo, até então "monopólio" do Estado. Contudo, não se trata aí de uma privatização ao estilo convencional, mas da constituição, para o setor privado, de uma espécie de reserva de mercado, onde as oportunidades de ganho podem ser bastante promissoras, já que são cerca de 4,5 milhões de servidores públicos no país. A criação de fundos de pensão complementares para servidores públicos, geridos pela iniciativa privada, aliás, é compromisso que faz parte do acordo do Brasil com o FMI assinado em agosto de 2002, e que foi tranqüilamente acatado pelo governo do PT na revisão feita em março de 2003.
} 
que resista a tamanha tentação, ainda mais se junto com ela vem o brinde da moeda doméstica revalorizada, que sustenta a ilusão de que um país como o Brasil possa vir a ter uma moeda de verdade, ou seja, incondicionalmente conversível. O ideário vigente nunca associa responsabilidade fiscal e "macroeconômica" (sic) à responsabilidade cambial.

Que os recursos que têm feito a festa do governo e da mídia, sobretudo a televisiva, venham não do lado saudável, mas do lado cigano, volátil, especulativo da balança de capitais, só agrava a situação. Caído em tentação, o país descuidará, mais uma vez, da divisa boa, que cria demanda efetiva e impulsiona crescimento e emprego, e estará definitivamente nas mãos do mercado, inteiramente refém de seus caprichos. Além de tudo, a tão decantada credibilidade pode ir à lona subitamente se por uma razão qualquer, fundamentada ou sem fundamento, verdadeira ou forjada, os mercados, hoje tão bem-humorados com o país, resolverem mudar de humor. Já vimos esse filme antes, por sinal muito recentemente, e sabemos que triste fim ele tem.

Mas por que não intervir? Não detém o Banco Central os instrumentos que lhe permitem enfrentar tanto quedas quanto elevações exacerbadas do valor da moeda doméstica? Aliás, não age ele sempre assim e quase automaticamente quando o movimento se dá no sentido inverso? Interlocutores de peso têm feito tal pregação, mas mesmo assim as autoridades econômicas não se dispuseram ainda a operar a reclamada intervenção. Parece-lhes uma heresia impedir a valorização da moeda nacional, mesmo que ela ocorra por obra e graça de capitais ariscos, pouco confiáveis e dispostos a dar no pé ao primeiro sinal de perigo. Não é demais frente a isso relembrar o lamento de Celso Furtado em entrevista concedida ao jornal Valor em junho de 2000: "Agora, o Brasil chegou ao extremo (...) O triste é imaginar que um país em construção seja entregue ao mercado".

Mais triste ainda, podemos completar agora, se essa entrega estiver sendo patrocinada pelo governo de um partido que nasceu, cresceu e fortaleceu-se na luta pela construção de uma nação soberana, capaz de tratar com dignidade todos os seus cidadãos. ${ }^{7}$ A "credibilidade", em cujo nome são exigidos tão pesados sacrifícios, é necessária para manter a vulnerabilidade do país, não sua estabilidade e a sustentabilidade de seu crescimento, incansavelmente reivindicadas pelo PT ao longo dos oito anos do reinado de FHC. É claramente falacioso, pois, o argumento da credibilidade, como falaciosa é a tese de que só há uma macroeconomia. Esta última só se sustenta se é a manutenção desse tipo de credibilidade o que está no horizonte. E a credibilidade/vulnerabilidade de economias como a brasileira é necessária para a valorização dos capitais especulativos que hoje dominam o processo de acumulação, como necessárias são as crises, as turbulências, os súbitos movimentos de preços das moedas fracas, as elevadas taxas reais de juros etc. É

\footnotetext{
7 “A palavra-chave é delivery, como bem empregou um analista de Wall Street. A gente está prometendo e a gente está entregando" (Otaviano Canuto, secretário de relações internacionais do Ministério da Fazenda, citado por Paulo Nogueira Batista Jr., em artigo na Folha de S. Paulo de 10 de abril de 2003).
} 
precisamente isso que produz a engorda do capital especulativo no mundo e o torna cada vez mais poderoso.

A afirmação peremptória de que existe uma única macroeconomia, independentemente da intenção com que é feita, esconde assim, atrás de sua aparente tecnicidade e neutralidade, o benefício de interesses muito específicos, que estão em linha com a virada pró-acumulação financeira do capitalismo mundial que começa no final dos anos 70, devasta a América Latina nos anos 90 e ainda está por aqui, firme e forte. Com sua política econômica, o governo do PT fortalece esse ideário, visto que, abraçada, defendida e aplicada pelo maior partido de esquerda do mundo no governo do maior país da América Latina, a política econômica vinculada a esses interesses ganha um inestimável reforço em sua imagem de política cientificamente comprovada.

Talvez se pudesse argumentar que, independentemente da verdadeira vontade do partido e do presidente eleito, a adoção desse modelo impôs-se como necessidade, dada a "herança maldita" que o governo anterior deixara. E como, uma vez embarcado nesse bonde não é possível dele saltar sem provocar um tumulto talvez maior do que aquele que se tentou evitar, o governo de Lula teria decidido de uma vez por todas, ainda antes de assumir, adotar o tal modelo e tentar firmemente, por mais que reconhecesse que ele não é o ideal para isso, encaixar nele seus verdadeiros objetivos (crescimento econômico, recuperação dos níveis de emprego, distribuição de renda etc.). Se comprovada, a tese traria pelo menos um alento: a escolha, pelo governo do PT, do modelo anticrescimento poderia ser considerada como uma irônica fatalidade.

É esse, como se sabe, o tipo de argumento que tem sido utilizado pelo governo: como o país se desfazia como gelatina em janeiro de 2003, tomar qualquer medida que jogasse mais lenha na fogueira da desconfiança seria uma temeridade que poderia colocar em risco a própria governabilidade. A queda do risco-país, a revalorização do real etc. seriam a comprovação do acerto da escolha.

Mas serão verdadeiras as premissas desse argumento? Já se demonstrou de maneira inequívoca que o país estava à beira do precipício no início da gestão Lula? Veremos que não. E não se provoca com isso nenhuma minimização dos descalabros cometidos pela gestão anterior. As perversas conseqüências para o país da política adotada pelo governo FHC são de natureza estrutural, enquanto o argumento com o qual se justifica a ortodoxia do início do governo Lula é de natureza indiscutivelmente conjuntural. Vejamos.

\section{DEZEMBRO DE 2002: O BRASIL À BEIRA DO PRECIPÍCIO?}

Que tipos de problema podem se agravar num país como o Brasil a ponto de se chegar a dizer que ele está à beira do precipício, requerendo, por isso, a adoção de medidas drásticas que visem reverter o quadro? O primeiro, sem dúvida nenhuma, é o risco da inadimplência externa, o famoso default, que o jargão economês 
houve por bem consagrar. O outro é o descontrole inflacionário, capaz de desorganizar o sistema produtivo e parar o país. Vejamos cada um deles.

A piora estrutural das contas externas do Brasil é certamente uma das mais perversas heranças legadas pelo governo FHC. A abertura externa estabanada, além de elevar a dependência externa do país em setores estratégicos como os de insumos básicos e bens de capital, produziu um substantivo estoque de capital privado nacional bom e barato que foi parar nas mãos do capital estrangeiro. O processo de privatização das estatais produtoras de serviços industriais de utilidade pública impôs o mesmo destino também a esse enorme estoque de capital. Como resultado, a balança de serviços é hoje muito mais pesada, por conta do aumento do déficit na balança de rendas, resultado inescapável da duplicação do passivo externo líquido do país. Além disso, o crescimento do produto depende agora, muito mais do que antes, das importações.

O déficit da balança de rendas (lucros, dividendos e juros), que girou em torno de US\$ 11 bilhões ao longo da década de 80 e nos anos 90 até 1996, salta para a esfera dos US\$ 15 bilhões em 97 e para US\$ 19 bilhões a partir de então. Esse estrago estrutural teve um componente adicional de natureza conjuntural de enorme peso com os quatro anos e meio de moeda nacional artificialmente valorizada.

Daí os megadéficits em transações correntes que passaram então a ser produzidos. ${ }^{8} \mathrm{O}$ componente conjuntural foi resolvido com a desvalorização do câmbio em janeiro de 1999. O estrutural permanece e só com mudanças estruturais (redução da dependência, diminuição do passivo externo) pode ser minorado.

Evidentemente, dada a piora estrutural das contas externas, nossa vulnerabilidade também cresceu e, na presença de componentes conjunturais também adversos, pode de fato produzir crises que coloquem o país à beira do precipício. Depois de janeiro de 99, o Brasil teve de recorrer ainda mais duas vezes ao FMI, ameaçado que estava de não honrar seus compromissos externos. A primeira delas foi em junho de 2001, quando o governo FHC, vendo cair por terra suas expectativas quanto ao volume de recursos de investimentos externos diretos que o país receberia, decidiu preventivamente recorrer ao Fundo, obtendo US\$ 15 bilhões. A segunda vez foi precisamente em agosto de 2002, quando a turbulência eleitoral provocada pela liderança de Lula e pelo terrorismo que se fez em torno disso, fez subir o risco-país, desvalorizar os títulos brasileiros no mercado externo e em conseqüência retrair a entrada de recursos na balança de capitais. Foram então obtidos US\$ 30 bilhões, entre saques e postergação de pagamento ao próprio Fundo de valores referentes a empréstimos anteriores.

Como se vê, se houve algum momento em que se pôde considerar que o país estava à beira do precipício (leia-se: à beira da insolvência externa), prestes a redu-

\footnotetext{
${ }^{8}$ Se tomarmos a somatória do saldo em transações correntes do Brasil no período 1984-1993, chegaremos a um déficit total no período de US\$ 1,3 bilhão. Se fizermos o mesmo exercício para a década seguinte, ou seja, para o período 1994-2003, supondo para 2003 o mesmo déficit verificado em 2002 (US\$ 7,7 bilhões), o resultado é um déficit total de US\$ 196 bilhões, ou seja, um resultado 150,8 vezes pior do que nos dez anos anteriores.
} 
zir suas reservas abaixo do mínimo exigido pelos organismos internacionais, esse momento foi em meados do ano, ou seja, julho e agosto, culminando com a assinatura do terceiro acordo com o FMI no exíguo período de três anos. Poder-se-ia argumentar que isso não foi suficiente para tirar o país daquela situação, uma vez que o valor em reais do dólar americano continuou a subir, enquanto o risco-país não cedeu. Mas serão esses bons indicadores para o que se está querendo medir? A verificação do comportamento do nível de reservas não produzirá uma indicação mais concreta? Quando se observa essa variável, porém, o que se nota é que ela apresenta um comportamento surpreendentemente estável ao longo de 2002 e em níveis muito semelhantes aos verificados ao longo de 2001. Elas começam o ano em cerca de US\$ 36 bilhões (a média de 2001 foi de US\$ 36,3 bilhões), oscilam para US\$ 33 bilhões em abril e maio, alcançam a faixa dos US\$ 40 bilhões em junho e julho, ficam na esfera dos US\$ 38 bilhões em agosto e setembro e de US\$ 36 bilhões no bimestre seguinte, fechando o ano em US\$ 37,8 bilhões. Note-se, além do mais, que fez parte do acordo com o FMI a redução de US\$ 10 bilhões no nível mínimo de reservas exigido (que cai então para US\$ 5 bilhões), uma cautela adicional que, como se vê, o Brasil não precisou utilizar.

Portanto, em dezembro de 2002, do ponto de vista das condições necessárias para honrar os compromissos externos, a situação estava equacionada. Além disso, e este talvez seja um elemento ainda mais importante, a balança comercial vinha apresentando resultados absolutamente surpreendentes, superando em cerca de $50 \%$ as previsões feitas pelo próprio governo. Assim, do ponto de vista da performance futura das contas externas, em dezembro de 2002 as expectativas eram muito melhores do que as existentes, por exemplo, um ano antes, quando se esperava um resultado positivo nessa área, porém não na magnitude do efetivamente obtido.

Em outras palavras, isto significa que, com o acerto do câmbio, as contas do comércio exterior começavam a caminhar na direção certa. É bem verdade que a redução no ritmo do crescimento econômico em 2002 deu uma mãozinha para a obtenção de resultados tão favoráveis, visto que reduziu o dispêndio previsto com as importações. Mas, analisando os dados mais detalhadamente, percebe-se que o resultado mais expressivo para a obtenção desses superávits vem mesmo do lado das exportações. Em dezembro de 2002, por exemplo, quem comparasse o valor das exportações e importações no período julho-novembro daquele ano com os mesmos valores no mesmo período do ano anterior, teria percebido um crescimento de cerca de US\$ 5,2 bilhões nas exportações contra uma queda de apenas US\$ 3,2 bilhões nas importações. Essa tendência, já perceptível no último mês de 2002, vem se confirmando integralmente em 2003. No período janeiro-maio de 2003 as exportações alcançaram um valor mais de US\$ 6 bilhões maior que o obtido no mesmo período de 2002, enquanto o valor das importações ficou praticamente estável: US\$ 19,1 bilhões em janeiro-maio de 2003, contra US\$ 19 bilhões no mesmo período de 2002.

Considerando então conjuntamente, de um lado, o comportamento do nível de reservas e, de outro, as boas perspectivas da balança comercial já claramente perceptíveis ao final de 2002, e considerando-se além do mais que já havia sido 
assinado o acordo com o FMI, o que permitiria enfrentar qualquer tempestade inesperada, fica muito pouco plausível a versão oficial de que as drásticas medidas monetárias e fiscais tomadas no início da gestão Lula teriam sido necessárias porque o Brasil "estava quebrado", “à beira do precipício”, "derretendo como manteiga", "desfazendo-se como gelatina" etc.

Mas o contra-argumento já está pronto: o problema era a inflação, que se mostrava completamente fora de controle. Iniciar o governo Lula permitindo um descontrole monetário dessa ordem seria como assinar logo de cara um atestado de incompetência e comprometer a viabilidade da gestão que se iniciava. Assim, a manutenção dos juros básicos em níveis reais substantivamente elevados teria se imposto como necessidade, bem como a elevação do compulsório dos bancos implementada em fevereiro.

Desde o início da gestão vendeu-se o argumento de que as taxas de juro só poderiam baixar quando a inflação cedesse. Por trás dele encontra-se o conservador diagnóstico de que o súbito surto de elevação de preços que o país experimentava era decorrente de inflação de demanda, já que só nesse caso uma taxa real de juros elevada pode ter algum papel para resolver o problema, uma vez que inibe os investimentos e pode conter o consumo, o mesmo podendo ser dito do corte de liquidez. Só nessas condições aliás é que se poderiam constituir novamente mecanismos informais de indexação que voltassem a jogar para a frente a inflação passada, reinaugurando um movimento muito conhecido da economia brasileira. Mas como defender tão implausível diagnóstico com a economia estagnada e o desemprego batendo recordes atrás de recordes? De onde poderia estar vindo tamanha pressão por reajustes de preços, a ponto de comprometer a estabilidade monetária do país?

Evidentemente o problema não era esse. Como é sabido, por conta justamente da turbulência provocada pelo processo eleitoral, o preço em reais da moeda americana disparou a partir de junho de 2002, atingindo quase $\mathrm{R} \$ 4$ em setembro. Com a defasagem que sempre existe nesses casos, os índices de preços passaram a incorporar esse choque a partir de outubro-novembro. Acrescente-se aqui que, na cesta de bens que dá a base para esses índices — portanto, também para o IPCA do IBGE, que é o índice acompanhado para efeitos do controle das metas inflacionárias - têm peso muito substantivo as tarifas de serviços industriais de utilidade pública, bem como os chamados preços administrados, como combustível, gás etc. Nessas circunstâncias era evidente que a absorção total do choque provocado pela elevação súbita do câmbio, mesmo com sua redução posterior (ele fecha o ano na faixa dos R \$ 3,50), demoraria alguns meses, visto que a assincronia existente no processo de reajuste de preços tornaria impossível que todo ele fosse absorvido de uma só vez. Portanto, fosse qual fosse a condução da política monetária, pelo menos quatro ou cinco meses de índices elevados existiriam como mera conseqüência da elevação do preço do dólar entre junho e setembro de 2002.

Não existia, pois, nenhum indicador de que o processo inflacionário estivesse fora de controle. Evidentemente esta elevação súbita de um dos preços mais importantes da economia teria conseqüências do ponto de vista do comportamento dos índices de preço, mas era perfeitamente possível saber a extensão do estrago. Ele 
estava limitado a uma reconfiguração da estrutura de preços relativos, que, ao fim e ao cabo, não é de todo ruim para a economia brasileira, senão ao contrário, visto que tende a reduzir os vazamentos e engrossar as injeções de demanda na economia doméstica. Não existia, por absoluta falta de oxigênio na economia, nenhuma possibilidade de essa reconfiguração de preços transmutar-se num descontrole monetário e/ou desencadear mecanismos informais de indexação que ressuscitassem a inflação inercial. Na ausência do câmbio, a âncora do sistema de preços estava e está na taxa de salário. ${ }^{9}$

A correção deste diagnóstico prova-se pela mera verificação da trajetória dos indicadores de preço entre o final de 2002 e o primeiro semestre de 2003. Todos eles, independentemente da cesta de bens que lhes serve de base, descreveram o mesmo movimento, a saber: elevação a partir de agosto-setembro, atingindo um pico em novembro, e queda acentuada a partir de dezembro-janeiro. O IPCA do IBGE, por exemplo, que chega a apresentar um crescimento de 3,02\% em novembro, cai para $2,1 \%$ e $2,2 \%$ em dezembro e janeiro respectivamente, reduzindo-se sustentadamente a partir de então, para atingir $0,22 \%$ de crescimento em maio. $\mathrm{O}$ IGP d.i., que assustara a todos com seus 4,21\% de crescimento em outubro e 5,84\% em novembro, já havia caído para $2,70 \%$ em dezembro, experimentando uma trajetória acentuadamente declinante a partir de então, a ponto de indicar uma deflação de $0,67 \%$ em maio. Ratificando essa interpretação, diz a economista Eulina Nunes, da equipe de índices de preço do IBGE, ao comentar a redução no ritmo de aceleração dos preços no início do ano: "A inflação não caiu por acaso. A inflação do ano passado foi eminentemente de custos, provocada pela alta do dólar" (Folha de S. Paulo, 15 de março de 2003). ${ }^{10}$

Portanto, também neste caso soa implausível o discurso governamental de que o caráter drástico das políticas monetária e fiscal impôs-se como necessidade para "afastar o país do precipício", "estancar o processo de derretimento da economia" etc. etc. Mas defender essa interpretação foi funcional para o governo em vários sentidos. Em primeiro lugar permitiu demonstrar à opinião pública a "correção" e "responsabilidade" da política adotada (Viram como a elevação dos juros era necessária, viram como eram necessários os cortes orçamentários? Está aí! Os índices inflacionários cederam!). Em segundo lugar permitiu também criar um espaço para a manutenção da taxa real de juros em nível tão elevado quanto estava quando

\footnotetext{
${ }^{9} \mathrm{O}$ rendimento médio do trabalhador na região metropolitana de São Paulo em dezembro de 2002 foi $8,8 \%$ inferior ao de dezembro de 2001. Além disso, a renda do trabalhador da indústria, medida pela folha de pagamento, cai ininterruptamente desde janeiro de 2002. Em abril de 2003, esse valor foi, em termos reais, 7,5\% menor do que o valor verificado em abril de 2002. Finalmente, os jornais têm mostrado que, quando se analisa o conteúdo dos acordos que vêm sendo feitos entre trabalhadores e empregadores, a inflação bate os salários em quase $50 \%$ deles.

${ }^{10}$ Mesmo com todas essas indicações e com a intensa queda verificada, o chefe da missão do FMI no Brasil, Jorge Márquez-Ruarte, foi capaz ainda de dizer, em abril, que o BC tinha de "agir de forma mais agressiva para controlar a inflação", dando a entender que era preciso elevar os juros e cortar ainda mais a liquidez da economia.
} 
o país mudou de mãos. Com todo o fetiche criado em torno do nível da taxa básica de juros e com o argumento incansavelmente repetido de que ela só cairia quando a inflação cedesse, abriu-se um espaço para a redução nominal da taxa com a manutenção ou mesmo a elevação de seu nível real. Por exemplo, a reunião do Copom de 18 de junho cortou em meio ponto percentual a taxa Selic, mas considerando que a expectativa inflacionária caiu da esfera dos $12 \%$ para alguma coisa abaixo de $8 \%$ em 2003, é evidente que a taxa real é agora (meados de junho) muito mais elevada do que no início do ano.

Mas se o perigo não vinha do front externo nem do descontrole monetário interno, que mais poderia ser alegado? Certamente o risco-país elevado, o dólar supervalorizado e o preço reduzido dos títulos brasileiros no exterior. Como vimos, porém, a redução do risco-país e a revalorização da moeda doméstica são antes perversos do que benéficos ao país. Eles podem aprofundar o verdadeiro precipício — social - em que o Brasil está metido há pelo menos uma década, preso que está nas armadilhas de um modelo no qual crescimento e emprego não são a prioridade.

\section{A SEDUÇÃO DO DISCURSO: A IDENTIFICAÇÃO ESPÚRIA ENTRE GESTÃO RESPONSÁVEL E POLÍTICA ECONÔMICA LIBERAL}

Retomando um ponto já anteriormente discutido, a defesa desse modelo, que se mostra como de validade universal por se apresentar como o único verdadeiramente científico, encobre na realidade interesses muito específicos que estão em linha com a primazia assumida pela valorização financeira frente à valorização produtiva desde o início dos anos 80 . Esse padrão de acumulação, se é ruim para os países do centro do sistema do ponto de vista de seus resultados sociais, para países como o Brasil é simplesmente nefasto.

A defesa desses interesses, porém, vem sempre embalada na retórica do respeito no trato da coisa pública, da necessidade de transparência, de austeridade, de gestão fiscal responsável, bandeiras extremamente sedutoras para a esquerda, que sempre as defendeu por aqui em função da folha corrida de corrupção e desmandos que caracteriza a história de nossa direita no poder. Quem em sã consciência pode ser contra a transparência e a gestão responsável dos recursos públicos, ainda mais num país como o Brasil? Mas, como os argumentos são vendidos conjuntamente, lê-se facilmente, por exemplo, a crítica à política monetária por sua demasiada austeridade como uma defesa da irresponsabilidade na gestão do dinheiro público. Confunde-se deliberadamente a União como ente da federação, que, enquanto tal, deve gerir responsavelmente os recursos orçamentários de que dispõe, com o papel do governo federal, enquanto planejador, enquanto autoridade monetária e produtor de moeda e de liquidez, enquanto gestor do crédito, enquanto guardião de reservas, enquanto sinalizador e promotor dos caminhos que a economia deve trilhar.

Graças a uma confusão de mesma natureza, associa-se também imediatamente política econômica liberal e estabilidade monetária, como se a política econômica não ortodoxa fosse necessariamente contra a estabilidade, cúmplice, portanto, 
de medidas que, ao fim e ao cabo, levam o país à hiperinflação. Assim, qualquer governo que busque uma alternativa será necessariamente irresponsável, visto que governo "responsável" é justamente aquele que evita essa rota, fazendo, para isso, "tudo o que for necessário". ${ }^{11}$

Mas essas confusões são, mais do que nunca, funcionais. O governo anterior não enfrentava grandes problemas nem entrava em contradição ao defender e praticar uma política econômica de corte liberal. Ele nunca pretendeu ser de esquerda, nem se preocupou efetivamente com o dilaceramento do país provocado pela desigualdade, que inescapavelmente se aprofunda com a adoção da política liberal. O presidente FHC chegou a dizer, numa longa entrevista ao "Mais!" da Folha de S.

Paulo em meados de 1996, que o modelo não era mesmo para os excluídos e dissertou tranqüilamente sobre qual seria o número deles (18, 26, 30 milhões?). ${ }^{12}$ Assim, ainda que se beneficiasse da identificação espúria entre gestão fiscal responsável e política econômica liberal, ela não era de fato necessária ao governo tucano.

Mas num governo do Partido dos Trabalhadores, com as limitações que sua história lhe impõe, é tão patente a contradição gerada com a adoção dessa política que esse embaralhamento torna-se uma necessidade. Mais ainda, é preciso estendêlo, prolongá-lo. As autoridades econômicas começaram por usar o jargão anterior, e falaram em responsabilidade fiscal; passaram depois a falar em responsabilidade macroeconômica, e agora, segundo determinação vinda do Palácio do Planalto, só se falará em "justiça social”: fome zero, cortes orçamentários, focalização dos programas sociais, megassuperávits, reforma da Previdência, juro real elevado, valorização artificial da moeda doméstica, tudo em nome da "justiça social".

\section{POLÍTICA ECONÔMICA NO GOVERNO LULA: LIMITES E ALTERNATIVAS}

Evidentemente a manutenção dessa postura deve enfrentar limites tanto sociais quanto políticos. O inegável carisma do presidente concede-lhe um precioso espaço para continuar a defender esse modelo. Contudo, mesmo isso é limitado. Tendo em vista a promessa, tantas vezes defendida na campanha eleitoral, de criação de 10 milhões de empregos, passado um ano ou ano e meio com o desemprego cres-

\footnotetext{
${ }^{11}$ Contudo, mesmo considerando o conceito de responsabilidade dessa forma estreita, a atual política teria de ser reprovada, dada a irresponsabilidade flagrante, com tamanha necessidade de produzir superávits, configurada no ato de patrocinar, via taxas de juros desnecessariamente elevadas, enormes transferências de recursos públicos aos setores da sociedade que menos carecem de renda.

12 O então presidente FHC equivocou-se nos números. Já em 1995, segundo dados do PNUD, havia 38 milhões de brasileiros vivendo abaixo da linha de pobreza de US\$ 1 per capita por dia e 70 milhões vivendo abaixo da linha de pobreza de US\$ 2 per capita por dia. (O que não quer dizer, como lembrou recentemente o professor Francisco de Oliveira, que, logo acima da linha, viva-se no paraíso do consumo...).
} 
cendo ao invés de cair, ${ }^{13}$ a positiva avaliação da população sobre o presidente Lula e o governo do PT pode não resistir. A continuidade do fosso social, com o crescimento do número absoluto de miseráveis ${ }^{14} \mathrm{e}$ a falta de perspectivas, aprofundará a violência nos grandes centros urbanos, por maiores que sejam os esforços envidados na área da Segurança Pública, e estimulará a indústria do narcotráfico, único "setor" que, para uma parcela substantiva da população, vem se mostrando "promissor" do ponto de vista do "emprego". Esse último elemento poderá fazer o governo cair em desgraça também junto às chamadas classes médias. Não se pode ainda esquecer que são setores substantivos dessas classes que serão diretamente afetados com a reforma da Previdência.

Os limites políticos dessa estratégia já vêm sendo sentidos desde o início do governo. Por maiores que sejam as habilidades do ministro chefe da Casa Civil e do presidente do Partido dos Trabalhadores, ficará cada vez mais difícil vender a interpretação de que a oposição aos projetos do governo dentro do PT e dos demais partidos de esquerda restringe-se a um grupelho de três ou quatro "radicais". Dados os princípios e os valores que sempre pontuaram a vida do Partido e a história vitoriosa de seu crescimento e afirmação, se o vento começar a soprar do lado contrário, o governo poderá muito rapidamente ficar em minoria. Mesmo que isso não chegue a acontecer, a oposição vinda do interior do próprio Partido tende a ficar cada vez maior e cada vez mais difícil de contornar.

É claro que esses limites sociais e políticos poderão não ser suficientes para deflagrar uma crise institucional. Uma vez que, na interpretação do professor Francisco de Oliveira, ${ }^{15}$ Lula venceu as eleições no vácuo social deixado pela desarrumação das classes promovida pelos oito anos de FHC, de modo que não se sabe mais quem comanda o quê, nem quem representa o quê, fica, nessas circunstâncias, mais fácil ao presidente exercer seu talento natural de "falar diretamente às massas" e compensar com os setores menos organizados da sociedade o apoio que irá perdendo nos setores mais organizados.

Evidentemente não estão também afastados os riscos de uma crise stricto sen$s u$ econômica, antes o contrário. Como demonstramos, o modelo estabilidade/ credibilidade é na realidade muito instável. Qualquer mudança de humor do mer-

\footnotetext{
${ }^{13}$ As conseqüências perversas da exacerbação desse modelo já se têm feito sentir nos indicadores de produto e emprego. O PIB no primeiro trimestre já apresenta uma queda de $0,1 \%$, evidentemente comprometendo o crescimento previsto pelo próprio governo para 2003, que começou estimado em $2,2 \%$, caiu para $2,0 \%$ e hoje já está em $1,6 \%$. Do ponto de vista da queda do emprego, os indicadores são os maiores desde 1994, tanto para o IBGE quanto para o Seade/Dieese.

${ }^{14}$ Mesmo que em termos relativos alguma pequena redução possa ser obtida com programas como o Fome Zero, o que tampouco é fácil, o número absoluto continuará a crescer, uma vez que o crescimento da população despeja a cada ano no mercado de trabalho centenas de milhares de brasileiros que não encontrarão onde empregar sua mão-de-obra em troca de uma renda monetária regular. Não disporão, por isso, de nenhuma forma "oficial” de acessar os bens e serviços que o paraíso do consumo apresenta todo dia na TV.

15 Conforme entrevista publicada na revista Reportagem $\mathrm{n}^{\circ} 41$, de fevereiro de 2003, concedida a Fernando Haddad e Leda Paulani.
} 
cado financeiro mundial com relação ao Brasil, variável aliás sobre a qual temos um poder de arbítrio muitíssimo limitado, pode desencadear um processo que, ao fim e ao cabo, leve de fato o país ao tão temido default. Desnecessário dizer que, nessas circunstâncias, em meio ao agravamento da questão social, a crise política será inevitável.

É bem verdade que, num caso como esse, o Grande Irmão do Norte poderá comparecer com sua ajuda. O atual presidente do Brasil, conforme cogitam alguns, está sendo guindado, com sintomático apoio americano, à posição de "líder mundial”, um convite difícil de recusar, e o Brasil, por conseguinte, sendo apresentado como uma espécie de vitrina das maravilhas da nova ordem mundial. Apesar do elevado preço a pagar, essa circunstância nos coloca numa situação muito diferente da que tem sido experimentada, por exemplo, pela Argentina nos últimos anos, tornando-nos, de uma certa forma, imunes a crises. Se a hipótese estiver correta, os constrangimentos enfrentados pelo governo Lula para efetivar as prometidas mudanças que implicam alteração no modelo econômico são muito maiores do que se pode imaginar à primeira vista.

Finalmente, é preciso frisar que, mesmo que tudo corra exatamente como o previsto, ou seja, que não haja crises sociais, nem políticas, nem econômicas, e que tudo dê certo, o que teremos, ao final da gestão Lula, mantido o atual modelo, será um crescimento medíocre, com muito boa sorte um pouquinho superior aos $2 \%$ ao ano obtidos na última gestão de FHC. ${ }^{16}$ Se a "credibilidade" continuar a engordar a balança de capitais, auxiliada pela manutenção de uma das mais elevadas taxas reais de juro do mundo, a revalorização da moeda doméstica prosseguirá e desmontará o que necessitou de uma violenta crise (janeiro de 1999) e mais um ano e tanto para ser montado. Junto com isso, redução de direitos, asfixia do debate, império do discurso único, em uma palavra, um totalitarismo de mercado que ficou apenas nos sonhos de FHC.

Mas qual seria então a alternativa? Ela existe, afinal? Como esperamos ter demonstrado, a idéia de que não há alternativa só se sustenta se o objetivo maior for manter o país nos marcos do tipo de "credibilidade" que aqui se descreveu. Se outros forem os objetivos, outra deverá ser a política econômica, e ela existe. A pretensão original do Partido dos Trabalhadores era comandar um governo "democrático e popular". Hoje parece claro que temos de nos conformar com algo bem menos pretensioso. Mas, mesmo para um governo simplesmente reformista, o que não seria pouco, considerada a atual quadratura da história capitalista, seria necessária muita mudança no que hoje se pratica. A começar, evidentemente, pelo nível excessivamente elevado da taxa real de juros, o que é claramente indicado tanto pelo cupom cambial da BM\&F quanto pela mera somatória da inflação esperada com a taxa de juros americana engordada pelo risco-país. E uma redução da taxa de juros não produziria apenas os inequívocos efeitos no nível de produção

\footnotetext{
${ }^{16}$ A julgar pelo que deve ocorrer neste ano de 2003 , para que essa média de $2 \%$ ao ano se efetive, o crescimento no período 2004-2006 terá de ser no mínimo de 2,7\% ao ano.
} 
e emprego. Ela seria capaz também de estancar o processo de apreciação desmesurada do real. Do ponto de vista inflacionário, inclusive, e se é para levar em conta as expectativas, melhor será a manutenção da subvalorização do que da sobrevalorização da moeda doméstica, já que a primeira aponta perspectivamente para a redução do valor em reais da moeda americana.

Quanto à política cambial propriamente dita, além da evidente necessidade de o Banco Central atuar como regulador do mercado, impedindo bruscas oscilações, poder-se-ia pensar na taxação do capital de curto prazo ou no estabelecimento de algum tipo de carência, em suma, pensar em regular, minimamente que seja, o movimento desses capitais. E já que se trata de gestão responsável, a responsabilidade cambial é o melhor antídoto contra a tentação do populismo cambial. No mesmo sentido, atrelar a queda da relação dívida/PIB à sobrevalorização da moeda (em função da substantiva parcela da dívida cuja valorização está atrelada ao comportamento do câmbio) é trocar uma melhora ilusória agora por uma piora potenciada no futuro, quando então se combinará o déficit fiscal que esfola com o déficit externo que mata... Por uma questão de aritmética elementar, a queda sustentada dessa relação só será possível aumentando a velocidade de crescimento do denominador e reduzindo a do numerador. Como subproduto dessa queda, também reduzida seria a necessidade de superávits fiscais, abrindo-se espaço para atuação efetiva da política econômica no sentido da indução do crescimento do produto e do emprego.

É pequena a exigência, como se vê. Para falar nos termos que são do agrado das autoridades econômicas, nada de invencionices, de mágicas, de expedientes mirabolantes. Apenas reformismo. Mas não implicaria tudo isto uma mudança de rota, uma sinalização de que a acumulação capitalista em nosso país voltará a ser pautada pela produção e não mais pelo mero rentismo? Evidentemente! E para operar essa mudança de rota, o governo do Partido dos Trabalhadores tinha, logo em seu início, um capital político inestimável, que talvez já tenha sido rifado. Hoje, para operá-la, serão necessárias, mais do que antes, coragem, vontade política e determinação. Mas não se diga que não há alternativa.

Persistir na atual política condenará o governo do PT ao mesmo destino do governo "socialista" de Felipe González na Espanha da década de 80. Como afirma José Luis Fiori em artigo de advertência publicado na Carta Capital (16 de abril de 2003): "Hoje, a distância e o tempo já permitem um balanço mais fiel do que foi a era González. E não há dúvida de que sua gestão ‘socialista' do capitalismo espanhol acabou ficando indiscernível da gestão conservadora e neoliberal do governo Thatcher". Assim, a continuar o que está aí, por maiores que sejam os contorcionismos retóricos das autoridades, não se poderá dizer outra coisa do governo Lula, senão que vai ficando mais e mais parecido com outro capítulo da era FHC, o mais melancólico decerto. 


\section{REFERÊNCIAS BIBLIOGRÁFICAS}

BATISTA JR., Paulo Nogueira (2003). "Paciência!”. Folha de S. Paulo, 10 de abril, p. B4.

BORGES NETO, João Machado (2003). "Um governo contraditório”. Revista da Sociedade Brasileira de Economia Política, $\mathrm{n}^{\circ} 12$, junho.

FIORI, José Luis (2003). “Mirem-se na Espanha”. Carta Capital, 16 de abril, pp. 50-52.

FURTADO, Celso (2000). Entrevista ao jornal Valor Econômico, 9 de junho.

OLIVEIRA, Francisco de (2003). "É preciso manter o estado de rebeldia”. Reportagem, $\mathrm{n}^{\circ}$ 41, fevereiro, pp. 17-22.

PAULANI, Leda Maria (2003). “Brasil Delivery”. Reportagem, n 44, maio, pp. 22-24. 